\title{
Karateristik Demografi, Sosial Dan Ekonomi Terhadap Alih Fungsi Lahan Petani Di Distrik Aimas Kabupaten Sorong
}

\author{
Zulkarnain Sangadji ${ }^{1}$, Uswatul Mardliyah ${ }^{2}$ \\ ${ }^{1}$ Dosen Fakultas Pertanian \\ ${ }^{2}$ Dosen Fakultas Ilmu Sosial dan Ilmu Politik \\ Universitas Muhammadiyah Sorong
}

\begin{abstract}
Abstrak
Kabupaten sorong merupakan salah satu kabupaten yang berada di provinsi Papua Barat yang dijadikan sebagai salah satu daerah pengembangan pertanian. Perilaku dan pola hidup mayarakat petani telah merubah penggunaan lahan pertanian ke non pertanian di beberapa wilayah di kabupaten sorong seperti pada Distrik Aimas. Distrik Aimas sebagai bagian dari Kabupaten Sorong mengalami peningkatan pembangunan yang begitu pesat sehingga berakibat pada pergeseran penggunaan lahan dari pertanian ke non pertanian. Penurunan produksi hasil pertanian akibat berkurangnya lahan akan menjadi permasalahan di masa yang akan datang.

Penelitian ini bertujuan untuk mengetahui karateristik demografi, sosial dan ekonomi terhadap alih fungsi lahan pertanian di Distrik Aimas. Metode yang digunakan adalah Metode penelitian sensus digunakan untuk mengumpulkan informasi dan data secara keseluruhan dari populasi tanpa diambil sampel. Metode ini dipilih karena jumlah penduduk yang masuk dalam kategori responden adalah yang mengalihkan lahannya pertaniannya ke non pertanian dikarenakan telah pindah, meninggal dunia, serta penduduk yang tidak melapor kepada kepala kelurahan atau ketua kelompok tani ketika mengalihfungsikan lahan pertaniannya

Berdasarkan hasil penelitian diketahui Karateristik demografi, sosial dan ekonomi kelurga petani , dimana 66,67 \% petani tergolongan dalam kelompok keluarga sedang dengan sebaran usia kepala keluarga tergolong masih produktif sebesar 33,33\% sedangkan tingkat pendidikan kepala kelurga didominasi oleh lulusan Sekolah Menegah Pertama (SMP) sebesar 50, $00 \%$. Minimnya pengetahuan dan keterampilan petani berdampak kepada aspek ekonomi keluarga petani.
\end{abstract}

Kata Kunci : Demografi, sosial, ekonomi, alih fungsi lahan

\section{PENDAHULUAN}

Peningkatan taraf hidup masyarakat petani tidak terlepas dari kualitas dan sumberdaya masyarakat setempat. Tingkat pendidikan yang rendah, jumlah angggota keluarga yang besar, usia kepala keluarga yang tidak produktif lagi, dan pendapatan hasil panen yang tidak memadai berdampak kepada perilaku dan pola hidup masyarakat petani yang pada akhir berimbas kepada alih fungsi lahan pertanian.

Kabupaten sorong merupakan salah satu kabupaten yang berada di provinsi Papua Barat yang dijadikan 


\section{Median Volume X Nomor 3 Bulan Oktober 2018}

sebagai daerah sentra pengembangan pertanian. Ketersediaan lahan bergatung pada banyaknya rumah tangga dan sistim kepemilikan lahan. Biasanya kepemilikan lahan petani berasal dari warisan, sewa tanah, dan bagi hasil. Dampak dari pertambahan penduduk dan pesatnya pembangunan telah merubah penggunaan lahan pertanian ke non pertanian di beberapa wilayah di kabupaten sorong seperti pada Distrik Aimas.

Distrik Aimas sebagai bagian dari ibu kota Kabupaten Sorong mengalami peningkatan pembangunan yang begitu pesat seperti, perumahan, sarana jalan, perkantoran sehingga menimbulkan dampak lain yaitu adanya pergeseran penggunaan lahan dari pertanian ke non pertanian. Penurunan produksi hasil pertanian akibat berkurangnya lahan akan menjadi permasalahan di masa yang akan datang. Olah karena itu sangat penting untuk mengetahui karateristik sosial, budaya, dan ekonomi petani terhadap alih fungsi lahan dari pertanian ke non pertanian di distrik Aimas kabupaten sorong. untuk

Adapun tujuan penelitian yaitu

Mengetahui karakteristik demografi, sosial, dan ekonomi petani di Distrik Aimas kabupaten Sorong.

\section{METODE PENELITIAN}

Metode penelitian sensus digunakan untuk mengumpulkan informasi dan data secara keseluruhan dari populasi tanpa diambil sampel. Metode ini dipilih karena jumlah penduduk yang masuk Tabel 1. Sebaran Kelompok Keluarga dalam kategori responden adalah yang mengalihkan lahannya pertaniannya ke non pertanian dikarenakan telah pindah, meninggal dunia, serta penduduk yang tidak melapor kepada kepala kelurahan atau ketua kelompok tani ketika mengalihfungsikan lahan pertaniannya. Oleh karena itu jumlah penduduk yang masuk dalam kategori responden yang ada tersebut diambil sebagai responden, walaupun jumlahnya sedikit.

\section{HASIL DAN PEMBAHASAN \\ a. Deskripsi Distrik Aimas}

Distrik Aimas memiliki luas wilayah sebesar $222.43 \mathrm{Km}^{2}$ dengan luas kawasan budidaya kurang lebih $400 \mathrm{Ha}$. Luas panen dan produksi padi di Distrik Aimas pada tahun 2016 masing-masing adalah $570 \mathrm{Ha}$ dan 2.000 ton. Rata-rata produksi padi sebesar 3,50 $\mathrm{Ku} / \mathrm{Ha}$. Selain padi, ubi kayu juga merupakan komuditas yang cukup anyak ditanam di Distrik Aimas sebanyak $21 \mathrm{Ha}$ untuk luas panen dan jumlah produksi 240 ton dengan rata-rata produksi sebesar 11,42 $\mathrm{Ku} / \mathrm{Ha}$ (BPS, 2017).

\section{b. Karateristik Demografi}

Hasil rekapitulasi karateristik keluarga petani di Distrik Aimas menunjukkan bahwa $66,67 \%$ menunjukkan keluarga sedang, 6,67\% katogori keluarga besar, dan sebanyak $33,67 \%$ termasuk katagori kecil. Struktur keluarga ini tidak belum termasuk ponakan, nenek, kakek atau lainnya di luar kelurga inti. Selengkapnya disajikan pada tabel 1 .

\begin{tabular}{cccc}
\hline No & Kelompok Keluarga & Frekuensi & Persentase \\
\hline 1 & Kecil & 10 & 33,33 \\
2 & Sedang & 18 & 66,67 \\
3 & Besar & 2 & 6,67 \\
& Jumlah & $\mathbf{3 0}$ & $\mathbf{1 0 0}$ \\
\hline
\end{tabular}

Sumber : Data primer yang diolah, 2018 
$\underset{\text { keluarga seperti ini }}{\text { Dengan seberan }}$ kelompok memerlukan biaya hidup yang cukup besar untuk memenuhi kehidupan keluarga. Hal ini juga merupakan salah satu faktor penyebab petani menjual lahannya atau mencari tambahan keuangan dibidang lain selain petani. Penyebab para petani menjual lahan sawah tidak dapat terelakan karena tidak adanya koperasi sebagai wadah simpan pinjam untuk memenuhi kebutuhan keluarga terutama keluarga dalam katagori keluarga sedang dan besar.

Berdasarkan informasi di atas dilakukan pengujian dengan metode Goodnes of Fit test yang diasumsikan beban hidup kelurga sebesar $60 \%$ dengan kepercayaan $90 \%$, maka diperoleh hasil $\mathrm{F}$ hitung 73,33 dan $\mathrm{F}$ tabel 21,06 sehingga informasi dari kepala keluarga benar adanya dimana tingkat biaya hidup petani sudah tidak dapat memenuhi standar hidup seharihari. Hal ini sesuai dengan pendapat Widyanti et.al (2009) bahwa semakin besar jumlah keluarga akan berdampak kepada peningkatkan biaya kebutuhan hidup.

Persentase kelompok usia kepala keluarga petani di distrik aimas tertinggi ditunjukkan oleh usia 41-50 tahun sebesar 53,33\% kemudian diikuti oleh kelompok usia $31-40$ tahun sebesar $33,33 \%$, dan terakhir kelompok usia 5160 tahun sebesar $13,34 \%$. Seperti terlihat pada tabel 2 dibawah ini.

Tabel 2. Sebaran Usia Kepala kelurga

\begin{tabular}{cccc}
\multirow{2}{*}{ No } & Kelompok Usia & \multicolumn{2}{c}{ Kepala Keluarga } \\
\cline { 3 - 4 } & $<30$ & Frekuensi & Persentase \\
\hline 1 & $31-40$ & 10 & 0 \\
2 & $41-50$ & 16 & 33,33 \\
3 & $51-60$ & 4 & 53,33 \\
4 & $>61$ & 0 & 13,34 \\
5 & Jumlah & $\mathbf{3 0}$ & 0 \\
& Kun
\end{tabular}

Hasil uji Koefisien Korelasi Spearman, nilai $\mathrm{R}=0,06 \%$, (tingkat hubungan antara usia dan produktifitas sangat kecil sekali).

Sumber; data primer yang diolah, 2018

Hasil uji korelasi spearman untuk melihat seberapa besar tingkat hubungan usia dengan produktivitas kerja petani di distrik aimas hanya sebasar $\mathrm{R}=0,06 \%$, tergolong sangat kecil. Hal ini dapat diartikan bahwa dengan tingkat seberan usia petani di distrik aimas sudah kurang produktif lagi dalam menggarap lahannya.

\section{c. Karateristik Sosial}

Tingkat pendidikan kepala kelurga petani di distrik aimas didominasi oleh lulusan sekolah menengah pertama sebesar 50,00 \% dikuti oleh lulusan sekolah dasar sebesar 46,67\% dan tidak sekolah sebesar 3,33 $\%$ sedangkan untuk lulusan sekolah menengah atas berdasarkan hasil surfei tidak ada atau $0 \%$. Sebaran tingkat pendidikan kepala keluarga petani di distrik aimas disajikan pada tabel 3.

Tabel 3. Sebaran Tingkat Pendidikan Kepala keluarga Responden 


\section{Median Volume X Nomor 3 Bulan Oktober 2018}

\begin{tabular}{cccc}
\hline No & Frekuensi Kepala Keluarga & Tingkat Pendidikan & Persentase \\
\hline 1 & 1 & Tidak Sekolah & 3,33 \\
2 & 14 & Lulus SD & 46,67 \\
3 & 15 & Lulus SMP & 50,00 \\
4 & 0 & Lulus SMA & 00,00 \\
\hline Jumlah & $\mathbf{3 0}$ & & $\mathbf{1 0 0}$ \\
\hline
\end{tabular}

Sumber; Data Primer yang diolah, 2018.

Pendidikan kepala keluarga petani tertinggi hanya tamatan SMP akan berpengaruh terhadap cara berpikir untuk memenuhi kebutuhan keluarga dengan keadaan ekonomi yang tidak mencukupi. Ditambahkan oleh Gunarsa dan Gunarsa (2008) bahwa tingkat pengatahuan kepala keluarga akan berdapak terhadap lingkungan keluarga dalam berkomunikasi dengan anggota keluarganya.

\section{d. Karateristik Ekonomi}

Petani responden di distrik aimas yang bekerja dibidang pertanian sebesar $73 \%$ sedangkan petani lainnya untuk memenuhi kebutuhan sehari-hari bekerja sebagai buruh bangunan sebesar 13,00 $\%$ dikuti oleh pekerjaan sebagai peternak sebesar $10,00 \%$, dan sebagai pedangan sebesar $7 \%$. Selengkapnya disajikan pada tabel 4 .

Tabel 4. Kareteristik Jenis Pekerjaan Tetap dan Sampingan.

\begin{tabular}{cccc}
\hline No & Jenis PekerjaanTetap & Frkuensi & Persentase \\
\hline 1 & Petani & 30 & 100 \\
& Jumlah & $\mathbf{3 0}$ & $\mathbf{1 0 0}$ \\
2 & Sampingan & Frekuensi & Persentase \\
a. & Buruh Bangunan & 4 & 13,33 \\
b. & Peternak & 3 & 10,00 \\
c. & Pedangan & 2 & 6,67 \\
d. & Tidak & 21 & 70,00 \\
\hline & Jumlah & $\mathbf{3 0}$ & $\mathbf{1 0 0}$ \\
\hline
\end{tabular}

Berdasarkan hasil penelitian $73 \%$ merupakan petani yang tidak mempunyai perkejaan sampingan dikarenakan minim pengetahuan dan keterampilan. Selain itu, tidak ditunjang oleh anggota kelurga yang lain. Keterbasan modal awal untuk mengarap lahan menjadi pemicu alih fungsi lahan dan banyaknya lahan tidur yang tidak dimanfaatkan secara maksimal oleh para petani seperti menanam sayuran dan jagung sebagai tambahan ekonomi untuk mencukupi kebutuhan sehari-sehari.

Petani yang mencari pekerjaan tambahan diluar sebagai dampak dari kurangnya modal awal pengelollan lahan juga tidak mampu monapang ekonomi keluarga karena hanya bertumpu kepada kepala keluarga, dimana tidak adanya peran keluarga dalam mendukung pendapatan, seperti dikemukakan oleh widyanti et.al (2009) bahwa adanya anggota keluarga yang berkeja akan berdampak baik dalam pemenuhan pendapatan ekomi keluarga.

\section{KESIMPULAN DAN SARAN Kesimpulan}

Karateristik demografi, sosial dan ekonomi kelurga petani , dimana 66,67 persen petani tergolongan dalam kelompok keluarga sedang dengan sebaran usia kepala keluarga tergolong masih produktif sebesar 33,33\%. Aspek 
ekonomi belum bisa memenuhi kebutuhan keluarga sedangkan tingkat pendidikan kepala kelurga didominasi oleh lulusan Sekolah Menegah Pertama (SMP) sebesar 50, $00 \%$.

\section{Saran}

Hasil penelitian yang ditemukan dilapangan maka dapat kemukakan beberapa saran :

1. Perlu adanya perhatikan khusus dari Pemerintah Kabupaten Sorong terkait bantuan dana kepada petani dalam pengelolaan lahan.

2. Perlu adanya pelatihan keterampilan terhadap petani sebagai alternatif pekerjaan yang dapat menambah ekonomi keluarga.

\section{UCAPAN TERIMA KASIH}

Terima kasih untuk Direktorat Riset dan Pengabdian Masyarakat (DRPM), Direktorat Jenderal Penguatan Riset dan Pengembangan, Kementerian Riset, Teknologi dan Pendidikan Tinggi, Sesuai Surat Perjanjian Penugasan Pelaksanaan Penelitian Nomor: 12/K14/AK/Kontrak Penelitian/2018, Tanggal 19 Februari 2018 atas bantuan pendanaan penelitian

\section{DAFTAR PUSTAKA.}

Arifin, Bustanul. 2007. Diagnosis Ekonomi Politik Pangan dan Pertanian. Jakarta: PT Raja Grafindo Persada.

BPS. 2017. Disrik Aimas Dalam Angka. Badan Pusat Statistik. Kabupaten Sorong.

Gunarsa S, Gunarsa Y. 2008. Psikologi Parktis: Anak, Remaja, dan Keluarga. Jakarta. BPK Gunung Mulia.

Irawan B. 2005. Konversi Lahan Sawah: Potensi Dampak, Pola Pemanfaatan dan Faktor Determinan. Pusat Penelitian dan Pengembangan Sosial ekonomi Pertanian, Bogor.

Irawan, Bambang. 2005. Konversi Lahan Sawah : Potensi Dampak, Pola Pemanfaatannya dan Faktor Determinan. Forum Penelitian Agro Ekonomi Vol. 23. No. 1. Tahun 2005. Bogor: Pusat Penelitian dan Pengembangan Sosial Ekonomi Pertanian.

Supangat, A. 2007. Statistika Dalam Kajian Deskriptif. Jakarta. Prenada Media Grafika.

Widyanti W, Suryahadi A, Sumarto S, Yumna A. 2009. The Relationship between chronic Poverty and Household Dynamics: Evidence From Indonesia/Jakarta: SMERU Research Institute. 